Scientific Electronic Archives

Issue ID: Sci. Elec. Arch. Vol. 14 (11)

November 2021

DOI: http://dx.doi.org/10.36560/141120211463

Article link: https://sea.ufr.edu.br/SEA/article/view/1463

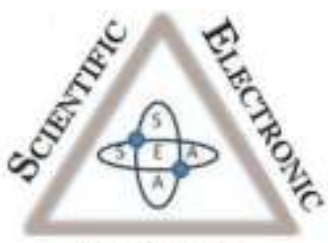

ArChIVEs

ISSN 2316-9281

\title{
Incomplete vaccination for conjugated meningococcal $C$ and hepatitis $B$ at municipal, state and federal level: 2015 a 2019
}

\author{
Mariana Dias de Borba \\ Universidade Federal de Mato Grosso, Campus de Sinop \\ Carlos Eduardo da Cunha Nascimento \\ Universidade Federal de Mato Grosso, Campus de Sinop \\ Gabriel Mael Sussuarana Silva Lobo \\ Universidade Federal de Mato Grosso, Campus de Sinop \\ Lucca Gonçalo de Castro Lima \\ Universidade Federal de Mato Grosso, Campus de Sinop
}

Camila Lays Winter

Universidade Federal de Mato Grosso, Campus de Sinop

Márcia Carolina Siqueira Paese

Universidade Federal de Mato Grosso, Campus de Sinop

Corresponding author

Pâmela Alegranci

Universidade Federal de Mato Grosso, Campus de Sinop palegranci@gmail.com

\begin{abstract}
Brazil has the National Immunization Program for disease prevention that offers nineteen vaccines, yet it is known that vaccination coverage according to age is not always reached. Thus, this study aimed to evaluate the vaccination coverage in the municipality of Sinop, in the Mato Grosso state and in the Brazil for meningococcal $\mathrm{C}$ conjugate vaccines and Hepatitis B in the period from 2015 to 2019. Method: This is a descriptive, retrospective and cross-sectional study, with data available in the Information System of the National Immunization Program. Results: Vaccination coverage for mingococcal C in children under one year in Sinop was above the target in 2015 and 2018 , Mato Grosso was above only in 2015, for the booster dose only Sinop was above the target in 2016. Coverage for hepatitis B in children under 30 days of life demonstrated that Sinop had coverage above the state of Mato Grosso, which in turn was above Brazil. For children under 1 year old, only in 2016 and 2019 the state presented greater vaccination coverage at the expense of Sinop and Brazil. Conclusion: The results demonstrate that there is hesitation on the part of the population regarding vaccination, being greater in vaccines such as meningococcal $\mathrm{C}$. Strengthening childcare is the key to improving the panorama of vaccine coverage

Keywords: Vaccine-Preventable Diseases, Hepatitis, Meningococcal Meningitis.
\end{abstract}

\section{Introduction}

The In Brazil, the National Immunization Program (PNI) started 48 years ago, which was developed for the organization and implementation of vaccines in the Brazilian calendar (Temporão, 2003; Lima \& Pinto, 2017). Since then, the calendar has had several vaccines that are available by the Ministry of Health, and remains the best form of prevention of several diseases (Lima \& Pinto, 2017).
In 1982, the first vaccine for hepatitis B (HepB) were licensed, which came from the plasma of patients with chronic infection, and from 1986 onwards, production was started using recombinant DNA technology (Coutinho, 2010). However, it was in 1998 that vaccination has been recommended in the first hours of life, and since then it has been offered by the PNI in order to prevent the disease and, especially, vertical infection (Brasil, 2017; 
Farias et al., 2020). The vaccination schedule was completed with the application of three doses (Brasil, 2017).

In 2010, the meningococcal C conjugate vaccine was implemented for children under 2 years old, following the basic scheme with a protocol of two doses, at three and five months, respectively, and a booster dose at 12 months (Brasil, 2018). The vaccine prevents diseases caused by the bacterium Neisseria meningitidis (meningococcus) and is contained oligosaccharide from serogroup C, a component of the bacterial capsule, conjugated to a protein (SBIM, 2019).

According to Sato (2018), a study with a historical series of vaccines in Brazil and in the world in recent decades showed a strong movement of hesitation among the population about vaccination in early childhood, such as measles, polio and DTP, for example. In addition, according to the authors, this scenario of variation in specific coverage led to the emergence of epidemics in the 2010s, such as measles in the states of Ceará, Pernambuco, Roraima and Amazonas (Brazil) (Sato, 2018).

Given this scenario, the vaccination situation allows knowing the reality of the regions, and it is essential that based on data analysis, measures are developed to promote vaccination. Thus, this study aimed to evaluate the vaccination coverage in the municipality of Sinop, Mato Grosso (Brazil) for meningococcal C conjugate and hepatitis $B$ vaccines, in the period from 2015 to 2019, comparing them with coverage in the state (Mato Grosso) and federal levels (Brazil).

\section{Methods}

This is a descriptive, retrospective and cross-sectional study. Data for the research were obtained through the Information System of the National Immunization Program (SI-PNI) made available by the Municipal Health Department of the city of Sinop (Mato Grosso). Data collections were carried out in August and September 2020.

The municipality under study is located in the northern region of the state of Mato Grosso, 480 $\mathrm{km}$ from the capital, Cuiabá. Sinop, according to the Brazilian Institute of Geography and Statistics (IBGE, 2021a), has an estimated population of 146,005 inhabitants and a land area of 3,990,870 $\mathrm{km}^{2}$. The state of Mato Grosso is located in the central-west region of Brazil and has an estimated population of $3,526,220$ inhabitants within a territory of $903,207.050 \mathrm{~km}^{2}$ (IBGE, 2021b).

Data were obtained from the city of Sinop, the state of Mato Grosso and Brazil, from 2015 to 2019. Vaccination coverage was obtained from the SI-PNI, and the results expressed as a percentage. The data collected were related to the administered doses for hepatitis B (HepB) and vaccination coverage for meningococcus $\mathrm{C}(\mathrm{MnC})$ and $\mathrm{HepB}$ in female and male children. The calculations, in the system, comply the following protocols:

Vaccine coverage of meningococcal $C$ conjugate. Vaccination coverage is considered by the system when the first two doses are applied (at three and five months), and the first booster dose at 12 months. The second booster dose, at 9 years old, was not considered in this study, because it was not available in the system. The calculation of this coverage uses as numerator the second applied doses of $\mathrm{MnC}$ vaccine at $<1$ year old, and as a denominator the population $<1$ year old (target population) given by the Information System on Live Births (SINASC), using as multiplication factor, 100. For the 12-month booster dose, the numerator and denominator are changed according to the target population. The national parameter for $\mathrm{MnC}$ vaccine reference is $\geq 95 \%$ (Brasil, 2014).

Hepatitis B Vaccine Coverage. HepB vaccine coverage was considered for children under 30 days (first dose in newborns) and for children under one year old, the latter being considered when applying the three doses of pentavalent vaccine (diphtheria, tetanus, whooping cough, hepatitis B and Haemophilus influenza type b). The calculation of this vaccination coverage for children under 30 days uses as the numerator the dose administered to the population with less than 30 days and as the denominator the target population given by the Information System on Live Births (SINASC). Vaccination coverage for children under one year old uses as the numerator the number of third doses of pentavalent applied at $<1$ year old and as the denominator the target population $<1$ year also registered in SINASC. The multiplication factor is also 100. The national parameter for this vaccine is $\geq 95 \%$ (Brasil, 2014).

The organization and analysis of data were performed using the Microsoft Office Excelß 2016 program and presented in a frequency distribution. All data used are of secondary origin and were analyzed in an aggregated way, without identifying individuals.

\section{Ethical principles and good practices in experimentation}

The Ethics Committee Research with Human Beings of the Federal University of Mato Grosso, Campus of Sinop (CEP/Sinop) approved the study (Approval number 3,636,377) and it was carried out in accordance with the resolution of the National Health Council number 466/2012 from the Ministry of Health.

\section{Results and discussion}

Data on the doses of meningococcal C conjugate vaccine applied in the city of Sinop were only available from the year 2018, and this year 2,546 children received the first dose, 2,563 the second dose and 2,341 the booster dose. In 2019, the first and second doses were vaccinated 2,842 and 2,691 children, respectively, and 2,709 booster doses were applied.

Regarding vaccination coverage for this same vaccine, between 2015 and 2019, there was a disparity between the basic regimen and the booster dose. Coverage in children under one year old was 
below the $95 \%$ target in the city of Sinop, as recommended by the Ministry of Health, in 2016 (91.725\%), 2017 (75.22\%) and 2019 (91.79\%) (Table 1).

The coverage considering the booster dose for $\mathrm{MnC}$ was also below the target, with $98.98 \%$ of the target population in the city of Sinop being reached in 2016 alone (Table 1). In the state of Mato Grosso and in Brazil, both in coverage in children under one year old and in coverage of the booster dose, the target was below $95 \%$ in most years analyzed, with the exception of 2015 in the state of Mato Grosso, where coverage for children under 1 year was $96.04 \%$ (Table 1).

Table 1. Vaccination coverage (\%) for meningococcal C conjugate in Sinop, Mato Grosso and Brazil, from 2015 to 2019

\begin{tabular}{lcccccc}
\hline & \multicolumn{3}{c}{$<1$ year (D1 e D2) } \\
\cline { 2 - 7 } Year & Sinop & Mato Grosso & Brazil & Sinop & Mato Grosso & Brazil \\
\hline 2015 & $116,05^{*}$ & $96,04^{*}$ & 92,84 & 83,99 & 82,23 & 80,52 \\
2016 & 91,72 & 94,07 & 89,39 & $98,98^{*}$ & 89,82 & 86,62 \\
2017 & 75,22 & 86,98 & 87,44 & 60,50 & 78,53 & 78,56 \\
2018 & $97,41^{*}$ & 88,92 & 88,49 & 88,19 & 80,20 & 80,22 \\
2019 & 91,79 & 88,89 & 85,62 & 91,89 & 88,49 & 84,43 \\
\hline
\end{tabular}

Source: National Immunization Program (PNI). D: corresponding to vaccine dose. * reached vaccination coverage.

The coverage of the meningococcal $\mathrm{C}$ conjugate vaccine at the municipal, state and federal levels showed that the percentages of children under one year and booster dose were, in their majority, lower than the goal recommended by the Ministry of Health between 2015 and 2019.

The long-term immunological protection of the meningococcal $C$ vaccine depends on the complete immunization schedule (Borrow \& Miller, 2006). Vaccine provides not only direct protection to the vaccinated individuals, but it also contributes to reducing the circulation of the bacteria in the community among non-vaccinated people (De Wals et al., 2011). Therefore, variations in specific coverage found in this study represent a risk of disease spread, similar to others diseases like measles in the states of Roraima and Amazonas (Sato, 2018).

The Italian meningococcal $C$ vaccine, for example, even being applied in just one dose, has not achieved satisfactory coverage rates since its implementation in 2013 (Signorelli, et al. 2018). In 2018, the French government measure that made children under two years old completed the scheme for eleven types of vaccine, managed to increase the coverage rates of the first dose of the vaccine from $39.3 \%$ to $75.7 \%$ in just one year (Lévy-Bruhl et al., 2019). This demonstrates the importance of public policies to achieve coverage targets vaccines.

For hepatitis $\mathrm{B}$, the doses were available since 2015 both for children under 30 days and for children under 1 year (Table 2), and within the five years studied; children under 30 days of life received the highest number of doses applied when compared to children under the age of one year. Regarding vaccination coverage, in the population aged less than 30 days, it was observed that in 2015 Sinop had the highest vaccination coverage rate $(144.87 \%)$, similar to what occurred in Brazil (89 $.02 \%)$. While in the state of Mato Grosso, it was in 2018 the highest coverage rate $(97.51 \%)$ (Table 3$)$.
The city of Sinop reached the coverage for hepatitis $B$ for population with less than 30 days of life, except in 2016 when almost reached the goal $(94,77 \%)$. This profile did not extend to the state of Mato Grosso and Brazil, nor for vaccination coverage in children under one year old for the three regions studied, with the exception of Sinop and Mato Grosso only in 2015. For population of children under one year old, the city was unable to maintain vaccination coverage rates above 90\% in 2017 and 2019, while in the state from 2017 the coverage for this age group was below $90 \%$. In Brazil, in 2019, there was an abrupt drop 69.65\%) compared to previous years (Table 3 ). The findings demonstrate the risk of creating conditions for the spread of hepatitis $B$.

In countries that managed to maintain vaccine coverage rates for $\mathrm{HepB}$, there was a reduction of $77 \%$ in cases of acute HBV infection between 2006 and 201416 (Miglietta et al., 2018). In Spain, the incidence of hepatitis $B$ was reported to be twice as low in groups with vaccination coverage above $70 \%$, when compared to a lower coverage (Oviedo et al., 2012).

As in the present study, the incompleteness of the vaccination schedule was also observed in a study carried out in São Luís, in the state of Maranhão (Brazil). The study assessed the completeness of the new vaccine schedule, such as meningococcal $\mathrm{C}$ and 10-valent pneumococcal, and showed that $32 \%$ of children born in 2010 did not complete the vaccine schedule (Silva et al. 2018).

The literature brings several factors as possible influences on variations in vaccination coverage. Vaccination hesitation may be the result of lack of knowledge about the vaccine, clarification about the vaccination schedule and the protection afforded (Succi, 2018). In addition to these factors, from the emergence of the new coronavirus, it was 
Table 2. Hepatitis B vaccine doses applied to children $<30$ days of life and children < 1 one year old from 2015 to 2019 in the city of Sinop, MT

\begin{tabular}{ccc}
\hline Year & Vaccine dose \\
\hline & $<30$ days of life & $<1$ year \\
\hline 2015 & 3574 & 2839 \\
2016 & 2608 & 2584 \\
2017 & 2666 & 2083 \\
2018 & 2864 & 2514 \\
2019 & 2974 & 1655 \\
\hline Total & 14686 & 11675 \\
\hline
\end{tabular}

Source: National Immunization Program (PNI).

Table 3. Vaccination coverage (\%) for Hepatitis B in children with $<30$ days of life and $<1$ year old, from 2015 to 2019 , in the city of Sinop, in the state of Mato Grosso and in Brazil

\begin{tabular}{lcccccc}
\hline \multirow{2}{*}{ Year } & \multicolumn{3}{c}{$<30$ days of life } & \multicolumn{2}{c}{$<1$ year } \\
\cline { 2 - 7 } & Sinop & Mato Grosso & Brazil & Sinop & Mato Grosso & Brazil \\
\hline 2015 & $144,87^{*}$ & $96,84^{*}$ & 89,02 & $115,08^{*}$ & $95,15^{*}$ & 91,03 \\
2016 & 94,77 & 88,25 & 80,11 & 93,9 & 94,87 & 87,91 \\
2017 & $96,88^{*}$ & 87,52 & 85,82 & 75,69 & 85,01 & 84,40 \\
2018 & $107,35^{*}$ & $97,51^{*}$ & 88,38 & 94,23 & 89,19 & 88,53 \\
2019 & $100,51^{*}$ & 81,71 & 77,48 & 55,93 & 71,45 & 69,65 \\
\hline
\end{tabular}

Source: National Immunization Program (PNI). * reached vaccination coverage.

observed that in some countries in Asia, such as Indonesia and India, there was a severe reduction in the vaccination coverage rate in 2020 (Sandhu et al., 2020).

The fact that there is no effective monitoring due to the low demand for health facilities can influence vaccination, especially those applied in early childhood (Moura, 1998). Reports from a study carried out in Ribeirão Preto (São Paulo, Brazil), showed that the demand for childcare is even greater at six months, because over this, the baby is already able to feed without relying exclusively on breast milk (Mello, Lima \& Scochi, 2007) and consequently the low demand for basic health units leads to disagreement with the vaccination card. Thus, the relationship between vaccination and childcare becomes important, in order to promote the health of children, ensuring their full development without, in adult life, problems arising from childhood (Del Ciampo et al., 2006).

European countries also encountered a wave of vaccination hesitation and responded firmly by making the updated vaccination booklet mandatory for school enrollment in some countries, such as Italy and France (Signorelli et al., 2018; Lévy-Bruhl et al., 2019). In the city of Sinop, this measure was also adopted in 2019, based on a bill ( $n$ o 3530/2019) (Brasil, 2019). This leads to believe that, in the coming years, the vaccine coverage studied will reach its goal in Sinop city.

Public strategies must be developed to prevent falls in immunization coverage, including vaccination campaigns duly published in local media, actively seeking out those who have not completed the scheme, and talk about the disease and the benefits of vaccination (Succi, 2018). These strategies proved to be positive and strongly associated with vaccination (Francisco et al., 2015).

\section{Conclusion}

It was observed that although the coverage rates of the meningococcal $\mathrm{C}$ conjugate vaccine are mostly above $80 \%$, the established goal of $95 \%$ has not yet been reached by the city of Sinop, as by the state of Mato Grosso and by Brazil, with exceptions for the city in 2015 and 2017, and for the state in 2015.

For vaccine coverage against hepatitis $B$, the city of Sinop reached the goal every year for children under 30 days, however, in the state of Mato Grosso (except in 2015) and Brazil the coverage were below the recommended in all years for children under 30 days of life.

Vaccination coverage is the best means of prevention; however, the two vaccines analyzed were below the recommended. Given this scenario, it is urgent to reassess the vaccination strategies adopted by the Unified Health System. Educational measures with the population and the strengthening of childcare in Basic Health Units can help to achieve the goal of vaccination coverage.

\section{Conflict of interest}

The authors declare no conflicts of interest.

\section{Acknowledgment}


The authors are grateful to FAPEMAT, Brazil (proc. no. FAPEMAT.0430113/2020 - Mariana Dias de Borba) and Propeq-UFMT (students with VIC UFMT - Carlos Eduardo Cunha Nascimento and Gabriel Mael Sussuarana Silva Lobo) for financial support with the scholarships.

\section{References}

BORROW R., MILLER E. Long-term protection in children with meningococcal $C$ conjugate vaccination: lessons learned. Expert Rev Vaccines. vol. 5, n. 6, p. 851-857, 2006. https:// doi.org/10.1586/14760584.5.6.851 .

BRASIL. Câmara dos Deputados. Projeto de Lei no 3530 de 2019. Dispõe sobre a obrigatoriedade da apresentação da caderneta de vacinação ou equivalente nos casos em que especifica. Brasília: Câmara dos Deputados, 2019. Disponível em: https://www.camara.leg.br/proposicoesWeb/prop m ostrarintegra?codteor $=176461$. Acesso em 16/fevereiro/2021

BRASIL. Ministério da Saúde. Boletim Epidemiológico de Hepatites Virais. Brasília: Ministério da Saúde; 2017. Disponível em: http://www.aids.gov.br/pt-br/pub/2017/boletimepidemiologico-de-hepatites-virais-2017.

BRASIL. Ministério da Saúde. Secretaria de Gestão Estratégica e Participativa. Departamento de Articulação Interfederativa. Caderno de Diretrizes, Objetivos, Metas e Indicadores: 2013-2015. Ministério da Saúde, Secretaria de Gestão Estratégica e Participativa. Departamento de Articulação Interfederativa. 2. ed. Brasília: Ministério da Saúde, 2014. 154 p.

BRASIL. Ministério da Saúde. Secretaria de Vigilância em Saúde. Departamento de Vigilância das Doenças Transmissíveis. Coordenação Geral do Programa Nacional De Imunizações. Informe técnico da ampliação da oferta das vacinas Papilomavírus humano $6,11,16$ e 18 (recombinante): vacina HPV quadrivalente $e$ Meningocócica C (conjugada), Brasília, mar. 2018.

COUTINHO, M.F.G. Adolescência: vacina contra hepatite B. Adolescência \& Saúde. vol. 7, p. 23-30, 2010.

DE WALS P., DECEUNINCK G., LEFEBVRE B., BOULIANNE N., DE SERRES G. Effectiveness of serogroup $C$ meningococcal conjugate vaccine: a 7 year follow-up in Quebec, Canada. Pediatr. Infect. Dis. J., vol. 30, p. 566-569, 2011. doi: 10.1097/INF.0b013e31820e8638 .

DEL CIAMPO L.A, RICCO R.G, DANELUZZI J.C, DEL CIAMPO I.R.L, FERRAZ I.S., ALMEIDA C.A.N. O Programa de Saúde da Família e a Puericultura. Ciên \& Saúd Coletiva. vol. 11, p. 739-743, 2006. https://doi.org/10.1590/S1413-81232006000300021
FARIAS N.S.O., HOLCMAN M.M., COMPRI A.P., SILVA C.R.C.D., FIGUEIREDO G.M., MOREIRA R.C., PINHO M.E.R., BERSUSA A.A.S., COELHO D.M., KOIZUMI I.K., SATO H.K., ARAUJO N.V.D.L., CAMINADA S. Occurrence of hepatitis $B$ in pregnant women and follow-up of exposed children in the State of São Paulo, Brazil, in 2012. Epidemiol Serv Saude. vol. 29, p. e2019443, 2020. doi: $10.5123 /$ S1679-49742020000200018 .

FRANCISCO PM, DONALISIO MR, GABRIEL FDE $J$, BARROS MB. Hepatitis $B$ vaccination in adolescents living in Campinas, São Paulo, Brazil. Rev Bras Epidemiol. vol.18, p. 552-567, 2015. https://doi.org/10.1590/1980-5497201500030003.

IBGE (a) Instituto Brasileiro de Geografia e Estatística. Diretoria de Pesquisas, Coordenação de População e Indicadores Sociais, Estimativas da população residente com data de referência $1^{\circ}$ de julho de 2020. Disponível em: https://cidades.ibge.gov.br/brasil/mt/sinop/panorama . Acesso em 23 mar 2021.

IBGE (b), Instituto Brasileiro de Geografia e Estatística. Disponível em: https://cidades.ibge.gov.br/brasil/mt/panorama. Acesso em 23 mar 2021.

LÉVY-BRUHL D., FONTENEAU L., VAUX S., BARRET A.S., ANTONA D., BONMARIN I., CHE D., QUELET S., COIGNARD B. Assessment of the impact of the extension of vaccination mandates on vaccine coverage after 1 year, France, 2019. Euro Surveill. vol. 24, p. 1-4, 2019. doi: 10.2807/15607917.ES.2019.24.26.1900301.

LIMA, A.A., PINTO, E.S. O contexto histórico da implantação do Programa Nacional de Imunização (PNI) e sua importância para o Sistema Único de Saúde (SUS). Scire Salutis. vol. 7, p. 53-62, 2017. https://doi.org/10.6008/SPC2236-

$\underline{9600.2017 .001 .0005}$

MELLO D.F., LIMA R.A.G., SCOCHI C.G.S. Health follow-up of children in poverty situation: between the routine and eventuality of daily care. Rev Lat Am Enfermagem. vol. 15, p. 820-827, 2007. doi: 10.1590/s0104-11692007000700017.

MIGLIETTA A., QUINTEN C., LOPALCO P.L., DUFFELL E. Impact of hepatitis $B$ vaccination on acute hepatitis $B$ epidemiology in European Union/European Economic Area countries, 2006 to 2014. Euro Surveill. vol. 23, p. 1-13, 2018. https://doi.org/10.2807/1560-7917.ES.2018.23.6.1700278.

MOURA, E.C. The relationship between the use of primary health care and infant health status at 12 months in a Brazilian community. Rev. Bras. 
Epidemiol. vol. 1, p. 79-87, 1998. https://doi.org/10.1590/S1415-790X1998000100008

OVIEDO M., MUÑOZ M.P, CARMONA G., BORRÁS E., BATALLA J., SOLDEVILA N., DOMÍNGUEZ A. The impact of immigration and vaccination in reducing the incidence of hepatitis $\mathrm{B}$ in Catalonia (Spain). BMC Public Health. vol. 12, p. 1-12, 2012. https://doi.org/10.1186/1471-2458-12-614

SANDHU H.S., ROESEL S., SHARIFUZZAMAN M., CHUNSUTTIWAT S., TOHME R.A. Progress Toward Hepatitis B Control - South-East Asia Region, 2016-2019. MMWR Morb Mortal Wkly Rep. vol. $69, \quad$ p. $988-992, \quad 2020$. doi: 10.15585/mmwr.mm6930a2

SATO A.P.S. What is the importance of vaccine hesitancy in the drop of vaccination coverage in Brazil? Rev Saude Publica. vol. 52, p. 1-9, 2018. https://doi.org/10.11606/S1518-

8787.2018052001199

SBIM. Sociedade Brasileira de Imunizações. SBP. Sociedade Brasileira de Pediatria. Vacinas meningocócicas conjugadas no Brasil: intercambialidade e diferentes esquemas de doses. Nota Técnica Conjunta, São Paulo, 2019. Disponível em https://sbim.org.br/images/files/notastecnicas/nt-meningo-sbim-sbp-220819-at110919071019.pdf . Acesso em 07 fev. 2021.

SIGNORELLI C., ODONE A., CELLA P., IANNAZZO $S$. Childhood vaccine coverage in Italy after the new law on mandatory immunization. Ann lg. vol. 30, p. 1-10, 2018. DOI: 10.7416/ai.2018.2227.

SILVA F.S., BARBOSA Y.C., BATALHA M.A., RIBEIRO M.R.C., SIMÕES V.M.F., BRANCO M.D.R.F.C., THOMAZ É.B.A.F., QUEIROZ R.C.S., ARAÚJO W.R.M., SILVA A.A.M.D. Incomplete childhood immunization with new and old vaccines and associated factors: BRISA birth cohort, São Luís, Maranhão State, Northeast Brazil. Cad Saude $\begin{array}{lllll}\text { Publica. } \quad \text { vol. } 34, \quad \text { p. } & 1-20,2018 .\end{array}$ https://doi.org/10.1590/0102-311X00041717

SUCCI R.C.M. Vaccine refusal: what we need to know. J Pediatr. vol. 94, p. 574-581, 2018. https://doi.org/10.1016/j.jped.2018.01.008 .

TEMPORÃO J.G. O programa nacional de imunizações (PNI): origens e desenvolvimento. Hist Cienc Saude Manguinhos. vol. 10, p. 601-617, 2003. https://doi.org/10.1590/S0104$\underline{59702003000500008}$ 